\title{
STRATEGI PEMBELAJARAN TEKNIK LOMPAT JANGKIT MELALUI METODE BERMAIN DI SEKOLAH DASAR
}

\section{(LEARNING STRATEGIES AND SKIPPING GAMES THROUGH JUMP TECHNIQUES THE METHOD OF PLAY IN ELEMENTARY SCHOOL)}

\author{
Beatrix Jetje Podung \\ Fakultas Ilmu Keolahragaan (FIK) \\ Universitas Negeri Manado \\ E-mail : beatrixjetjepodung@gmail.com
}

\begin{abstract}
Abstrak: Penelitian ini bertujuan untuk memperoleh gambaran sejauhmana penerapan strategi pembelajaran teknik melompat jangkit dengan melalui metode bermain dapat meningkatkan prestasi siswa di sekolah dasar. Metode Penelitian yang digunakan yaitu metode eksperimen sedangkan subjek penelitian ini yaitu siswa kelas 5 Sekolah Dasar yang berjumlah 35 siswa.Hasil penelitian menunjukkan bahwa peserta didik lebih aktif terlibat dalam kegiatam pembelajaran, mereka antusias melakukan lompat jangkit sambil bermain, sehingga dapatlah disimpulkan bahwa peserta didik merasa senang melakukan lompat jangkit dengan metode bermain,demikian juga ketika siswa melakukan kesalahan maka dengan kesadaran dan tanggung jawab siswa segera melakukan push up dengan senang sebagai hukuman tanpa diminta oleh guru.
\end{abstract}

Kata kunci: Teknik Lompat Jangkit, Bermain, dan Sekolah Dasar

\begin{abstract}
This study aims to describe how far that application of learning strategic jump technique transmissible by playing methods to improve student achievement in elementary school. Result showed that students more actively involved in learning, they do jump transmissible enthusiastic while playing, so it can be concluded students feel happy to do the jump transmissible by playing methods, as well as students make the mistake of awareness and responsibility of learners doing push up with pleasure as punishment without being asked by the teacher.
\end{abstract}

Keywords: Transmissible Jump Technique, Playing, Physical, and Elementary School

Pendidikan Jasmani sebagai bagian dari Pendidikan jasmani yang dalam proses pendidikan secara keseluruhan, penyelenggaraan suatu program pendimasih sering diartikan dan diinterpres- dikan ikut mendukung dan membantu tasikan sebagai kegiatan pengajaran tercapainya tujuan pendidikan anak yang berupa aktifitas fisik dan demi fisik didiknya. Untuk itu keberadaan program itu sendiri. Kerancuan dalam pemaha- pendidikan jasmani merupakan bagian man pendidikan jasmani nampaknya penting dalam pendidikan di sekolah, masih banyak dan justru terdapat pada oleh karena itu pendidikan jasmani tidak kalangan guru pendidikan jasmani itu boleh dianggap sebgai suatu yang bisa sendiri. Masih banyak para guru pen- diabaikan atau sebagai pelengkap dalam didikan jasmani sendiri belum mema- penyelenggaraan kurikulum sekolah. hami sepenuhnya paradigm baru tentang Menyikapi hal tersebut maka pendidikan pendidikan jasmani disekolah, umumnya jasmani di sekolah tidak bisa dianggap mereka rata-rata masih menerapkan hanya sebagai pelajaran pelengkap saja, pendidikan olahraga yang selama ini karena dengan pendidikan jasmani yang dilaksankan di sekolah. Namun sebe- baik dan teratur bisa membantu pernarnya sangat berbeda sekali arti dan kembangan dan pertumbuhan anak, baik makna dari keduanya seperti yang secara jasmani maupun rohaninya. terdapat pada falsafah dan pendidikan Berdasarkan slogan "Mensana in corpora jasmani.

sano" atau didalam tubuh yang sehat tedapat jiwa yang sehat, maka untuk 
mencapai tubuh sehat bagi siswa sekolah pertumbuhan dan perkembangan dasar (SD) dibutuhkan peran serta upaya jasmani juga rohani secara menyeluruh guru untuk melakukan perubahan dalam yakni : kognitif, afektif dan psikomotor. pembelajaranya. Guru yang biasanya dalam pembelajaran pendidikan jasmani hanya meminta siswa melakukan senam pendidikan jasmani, guru mengajarkan massal saja, Sebagai pembaharuan guru berbagai keterampilan gerak dasar, harus mampu menerapkan strategi teknik dan strategi permainan olahraga pembelajaran teknik lompat jangkit internalisasi nilai-nilai (sportivitas, dalam melalui metode bermain. Berda- kejujuran, kerja sama, dan sarkan uraian tersebut permasalahan kebersamaan), dan pembiasaanyang ingin dicari jawabnya yaitu pembiasaan hidup sehat yang terus sejauhmana penerapan strategi pembela- diamati dalam setiap pembelajaranya, jaran teknik melompat jangkit dengan bukan melalui pengajaran konvensional melalui metode bermain dapat mening- didalam kelas yang bersifat teoritis. katkan prestasi siswa. Atas dasar Aktivitas-aktivitas yang dibeberkan permasalahan dimaksud maka tujuan dalam pengajaran pendidikan jasmani, penelitian ini yaitu untuk memperoleh sehingga aktivitas yang dilakukan dapat gambaran sejauhmana strategi pembela- mencapai tujuan pengajaran yang baik. jaran teknik melompat jangkit dengan melalui metode bermain dapat meningkatkan prestasi siswa di sekolah dasar.

\section{KAJIAN PUSTAKA}

\section{Pengertian Pendidikan Jasmani}

Pendidikan Jasmani adalah belajar ja dimanipulasi dalam bentuk kegiatan harmonis dalam rangka membentuk fisik, seperti melalui permainan dan manusia Indonesia seutuhnya yang olahraga yang didalamnya mengandung berkualitas berdasarkan pancasila nilai-nilai, sikap dan berperilaku positif. (Mutohir, 1996 : 4). Sementara itu, Belajar keterampilan gerak dapat Bucher (1983) berpendapat bahwa diartikan sebagai suatu rangkaian proses pendidikan jasmani sebagai bagian dari pembelajaran gerak yang dilakukan integral dari proses pendidikan secara secara sistematis, terarah dan terencana. keseluruhan yang mempunyai tujuan dan Secara spesifik hakekat pendidikan sasaran untuk meningkatkan jasmani yaitu sebagai berikut: 1) keterampilan manusia melalui media Pemenuhan hasrat untuk bergerak; 2) akitivitas jasmani yang telah diseleksi, Pengembangan kesegaran jasmani yang dengan maksud mencapai tujuan. berkaitan dengan unsur keterampilan (Bucher 1983 : 3). Sedangkan menurut motoric dan kesehatan (komponen kurikulum, pendidikan jasmani adalah kebugaran fisik); 3) Pengembangan proses melalui penyediaan penglaman keterampilan; 4) Mentransformasikan belajar kepada peserta didik berupa nilai-nilai, antara lain appresiasi, percaya aktivitas jasmani, bermain dan diri, harga diri, kooperatif, tanggung berolahraga yang direncankan secara jawab, sportifitas, komperatif dan sistematis guna merangsang budaya hidup sehat; 5) Merangsang pertumbuhan dan perkembangan fisik, 
keterampilan motorik, keterampilan Hal lain yang perlu diperhatikan ialah berfikir, emosional, social dan moral. bahwa perubahan-perubahan tersebut Pembekalan pengalaman belajar itu terjadi karena pengalaman ini diarahkan untuk membina, sekaligus membedakan dengan perubahan-perumembentuk gaya hidup sehat dan aktif bahan lain yang disebabkan oleh sepanjang hayat. (Depdiknas $2002: 1$ ). kemasakan (kematangan).

Walaupun pendidikan jasmani Banyak ahli berpendapat bahwa berbeda-beda, tetapi mengandung belajar merupakan suatu proses yang persamaan dan dapat ditarik kesimpulan. asosiatif, yaitu asosiasi atau koneksi Pendidikan melaui gerak jasmani, dan antara suatu rangsangan tertentu dapat dikatakan lebih lanjut bahwa (stimulus) dengan reaksi tertentu pendidikan jasmani pada hakikatnya (respon). Sementara itu ada yang adalah proses pendidikan yang kegi- menyatakan bahwa belajar secara atanya melibatkan interaksi antara sederhana memang dapat terjadi secara peserta didik dengan lingkungan yang asosiatif, tetapi dalam proses belajar dikelola melalui akitivitas jasmani secara yang rumit, kompleks, persepsi serta sistematis menuju pembentukan manusia pengertian akan situasi secara sutuhnya. Aktivitas jasmani yang dima- keseluruhan lebih memegang peranan. ksud adalah kegiatan untuk mening- Selain itu belajar tidak semata-mata katkan keterampilan motoric dan nilai- merupakan suatu akibat dari kondisi nilai fungsional yang mencakup kogitif, dalam lingkungan seperti pada modelafektif dan social. Melalui pendidikan model belajar klasikal dan instrumental jasmani diharapkan seseorang dapat conditioning, tetapi juga bisa terjadi sehat, segar jasmaninya seiring dengan karena mencontoh perilaku yang terjadi perkembangan keterampilan, pengemba- di sekitarnya.

ngan nilai sikap dan minta peserta didik.

Aktivitas-aktivitas tersebut mencermin- Menurut pendekatan kontruktikan kesesuaian tujuan akhir, yaitu visme, belajar adalah membangun dan pendidikan secara utuh.

\section{Teori Pembelajaran}

memantapkan pengetahuan sebagai hasil transformasi pengalaman yang dilakukan melalui aneka ragam interaksi peserta didik dengan sumber. Dalam

Belajar merupakan salah satu psikologi pendidikan prinsip yang paling bentuk perilaku yang amat penting bagi penting menurut teori konstruktivis kelangsungan hidup manusia. Belajar adalah guru tidak hanya sekedar membantu manusia menyesuaikan diri memberi pengetahuan kepada peserta (adaptasi) dengan lingkungannya. didik, peserta didik sendiri membangun Dengan adanya proses belajar inilah pengetahuan di dalam pikirannya. Guru manusia bertahan hidup (survived). memberikan kemudahan dalam proses Belajar secara sederhana dikatakan belajar dengan meberikan kesempatan sebagai proses perubahan dari belum kepada pesrta didik menemukan sendiri mampu menjadi sudah mampu, terjadi dan mengajar peserta didik menjadi nalar dalam rangka waktu waktu tertentu. dan secara sadar menggunakan strategi Perubahan yang itu harus secara relative mereka sendiri untuk belajar. Hal bersifat menetap (permanen) dan hanya tersebut diperjelas oleh Slavin tidak terjadi pada perilaku yang saat ini (1994:225) bahwa "the teacher can give nampak (immediate behavior) tetapi juga student that lead to higher pada perilaku yang mungkin terjadi di understandings, yet student themselves masa mendatang (potential behavior). must clim these ladders". Hal tersebut 
mengisyaratkan bahwa guru dapat Bucher. C.A., (1983) mengemumemberi jalan dan kesempatan kepada kakan bahwa pembelajaran pendidikan peserta didik yang dapat membantu jasmani dapat disebut ilmu apabila mereka mencapai tingkat pemahaman memenuhi karakteristik sebagai berikut: yang lebih tinggi, namun harus a) memiliki daya ramal dan kontrol diupayakan agar peserta didik sendiri terhadap hasil belajr; b) dapat dievaluasi yang melalui jalan tersebut (slavin, secara sistematik dan dapat dipecah 1994:225).

\section{Hakikat Pembelajaran}

\section{Pengertian Pembelajaran}

Pembelajaran adalah operasionalisasi dari kurikulum, dalam hal ini adalah gari-garis besar program pembelajaran. Pembelajaran di sekolah terjadi terjadi apabila terdapat interaksi guru dan peserta didik dengan lingkungan pembelajaran yang diarahkan untuk mencapai tujuan pembelajaran. Pembelajaran merupakan upaya membelajarakan peserta didik, yang secara implisit terlihat bahwa dalam pembelajaran ada kegiatan memilih, menetapkan dan mengembangkan metode untuk mencapai untuk mencapai hasil yang diinginkan. Dari definisi ini dapat dikatakan bahwa pembelajaran adalah upaya guru yang bertujuan dalam artian bahwa tujuan tersebut adalah guru membelajarkan peserta didik untuk mencapai Tujuan belajar.

Pembelajaran dapat diartikan sebagai upaya menciptakan kondisi yang memungkinkan peserta didik dapat belajar. Pembelajaran merupakan upaya untuk membelajarakan peserta didik, pembelajaran lebih mengutamakan pada bagaimana upaya guru mendorong atau memfasilitasi pesrta didik belajar, bukan pada apa yang dipelajari peserta didik. Istilah pembelajaran adalah menggambarkan bahwa peserta didik lebih banyak berperan dalam mengkonstruksikan pengetahuan bagi dirinya dan bahkan pengetahuan itu bukan hasil transformasi dari guru. menjadi rangkaian kegiatan yang dapat dikuasai; c) mengandung pemahaman tentang tingkah laku, desai instruksional, penyampaian dan manajemen; d) berkaitan erat dengan prinsip belajar seperti kesiapan, mo-tivasi, pelatihan, umpan balik dan kemajuan secara urutan; e) di mung-kinkan untuk mengkaji pengjaran "Teoritical Scientific Perspektif"

Berdasarkan karakteristik pembelajaran tersebut di atas dapat disimpulkan bahwa pendidikan jasmani sebagai salah satu kompponen pembelajaran tidak akan berarti, apabila guru mengalami kesulitan dalam memahami dan melaksanakan pembelajaran. Jika implementasinya dapat dicapai pembelajaran pendidikan jasmani, maka guru diharapkan dapat menigkatkan kemampuannya dalam melaksanakan proses pembelajaran sesuai dengan tuntan kurikulum yang berlaku. Berdasarkan hal tersebut menunjukkan, bahwa melalui pembelajaran pendidikan jasmani peserta didik diharapkan memiliki pengembangan keterampilan gerak, pemahaman kognitif, dan sikap positiff terhadap aktivitas jasmani, agar kelak menjadi manusia dewasa yang sehat, segar jasmani dan rohaniserta memiliki kepribadian yang mantap. Apabila kita kaji lebih jauh lagi tentang konsep pengajaran, maka konsep pengajaran mengandung konotasi guru, sedangkan konsep peserta didik adalah yang aktif belajar. Konsep pengajaran dan konsep pembelajaran dapat disimpulkan tidak mengandung makna yang berbeda dan sering digunakan secara bergantian. Pengajaran lebih menekankan upaya guru dalam mem- 
belajarkan peserta didik mencapai tujuan dengan belajar pendidikan jasmani kurikulum. Adapun pembelajaran mene- mengemukakan pendapatnya bahwa kankan pada proses yang menggam- kesiapan fisik dan mental untuk belajar barkan peserta didik lebih banyak apa saja merupakan komponen dalam berperan dalam mengkonstruksi penge- belajar keterampilam/skill adalah kesitahuan bagi dirinya dan pengetahuan itu apan. Kesiapan belajar mengarah pada adalah bukan hasil transformasi dari kesadaran menerima instruksi dan guru.Jadi pembelajaran adalah upaya pencapaian tujuan, karena setelah belajar untuk membelajarkan peserta didik diharapkan terjadi perubahan dalam diri melalui kegiatan proses belajar mengajar peserta didik/peserta didik yang belajar. atara guru dengan peserta didik dalam Misalnya dari tidak tahu menjadi tahu, mengembangkan metode untuk hasil dari tidak bisa melakukan menjadi bisa yang diinginkan.

\section{Tujuan Pembelajaran}

Tujuan utama pendidikan jasmani yaitu membantu peserta didik agar dapat meningkatkan keterampilan gerak mereka. Di samping itu, agar peserta didik mersa senang dan mau berpartisipasi dalam berbagai aktivitas. Tujuan ini mengisyaratkan, apabila peserta didik telah memiliki fundasi keterampilan gerak, dan sikap yang positif terhadap aktivitas jasmani, maka kelak akan menjadi manusia dewasa yang sehat dan daya cipta sering digunakan dalam segar jasmani dan rohani serta memiliki kegiatan manusia sehari-hari, sering pula kepribadian yang mantap. Untuk men- ditekankan pentingnya pengembangan capai tujuan ini diharapkan guru tidak kreativitas baik pada anak didik, pegawai berperan sebagai pemberi pengetahuan negeri maupun pada mereka yang tetapi lebih berperan sebagai fasilitator berwiraswasta. Kreativitas biasanya yang memungkinkan peserta didik dapat diartikan sebagai kemampuan untuk mengaktifkan seluruh unsur dinamis menciptakan suatu produk baru. Atau , dalam proses belajar, yang dapat meng- mungkin saja berupa gabungannya, arahkan peserta didik pada kegiatan kombinasinya, sedangkan unsur-unsur konstruksi ilmu pengetahuannya. Tujuan yang sudah ada sebelumnya, kombinasi yang dimaksud adalah hasil belajar. Di baru, atau melihat hubungan-hubungan samping pendapat lainnya yang dike- baru antara unsur, data, atau hal-hal yang mukakan, proses belajar pada individu- sudah ada sebelumnya.

individu di sekolah merupakan factor

penentu keberhasilan belajar, oleh sebab itu maka terlebih dahulu diperlukan mpuan untuk melihat asosiasi antara halsuatu rancangan pembelajaran yang hal atau obyek-obyek yang sebelumnya formal dan sistematis. Hal tersebut tidak ada atau tidak tampak hubumengindikasikan bahwa pengetahuan ngannya. Seorang anak kecil asyik atau keterampilan yang dicapai peserta bermain dengan balok-balok yang didik adalah sebagai hasil belajar dan mempunyai bentuk dan warna yang pembelajaran yang diterimanya di bermacam-macam, setiap kali dapat sekolah. Pendapat lain yang berkaitan menyusun sesuatu yang baru, artinya 
baru bagi dirinya karena karena menghambat aktivitas dan kreativitas sebelumnya ia belum pernah membuat peserta didik.

hal yang semacam itu. Anak ini adalah anak yang kreatif, berbeda dengan anak Fungsi Bermain dalam Pendidikan lain yang hanya membangun sesuatu jika Jasmani ada contohnya.

Terdapat empat prinsip dasar sinektik tentang kreativitas. Pertama, kreativitas merupakan sesuatu yang penting dalam kehidupan sehari-hari. Hampir semua manusia berhubungan dengan proses kretivitas, yang dikembangkan melalui seni atau penemuanpenemuan barulebih jauh bahwa Gordon menekankan bahwa kreativitas merupakan sebagian dari kehidupan kita sehari-hari dan berlangsung sepanjang hayat. Kedua, proses kreatif bukanlah sesuatu yang misterius. Hal tersebut dapat diekspresikan dalam gerakan dalam lompat jangkit atau mungkin membantu orang secara langsung untuk meningkatkan kreativitasnya. Secara tradisional, kreativitas didorong oleh kesadaran yang member petunjukuntuk mendeskripsikan dan menciptakan prosedur latihan lompt jangkit yang dapat diterapkan dalam pembelajaran pendidikan jasmani di lingkungan sekolah atau lingkungan lain. Ketiga, penemuan kreatif sama dalam semua bidang, baik dalam bidang seni, ilmu, maupun rekayasa. Selain itu, penemuan kreatif ditandai oleh beberapa proses intelaktual. Keempat, berpikir kreatif secara individu maupun kelompok adalah sama. Individu dan kelompok menurunkan ide-ide dan produk dalam berbagai hal.

Proses pembelajaran pada hekatnya adalah untuk mengembangkan aktivitas dan kreativitas peserta didik, melalui berbagai interaksi dan pengalaman belajar. Namun, dalam pelaksaannya seringkali tidak disadasari guru, bahwa masih banyak kegiatan pembelajaran yang dilaksanakan justru

\section{Teknik Dasar Lompat Jangkit}

Lompat jangkit biasa juga disebut dengan lompat jingkat atau lompat tiga (triple jump). Namun istilah atau nama yang resmi digunakan di Indonesia, yaitu yang tercantum di dalam buku peraturan perlombaan yang dikeluarkan oleh Persatuan Atletik Seluruh Indonesia (PASI) adalah Lompat Jangkit (HOP STEP JUMP). Berdasarkan teori pada buku peraturan perlombaan dan AD/ART PASI 1990-1991 pasal 174 ayat 1 dan 2 yang menyebutkan: 1) Lompat jangkit adalah suatu lompat yang terdiri dari jingkat (HOP), sebuah langkah (STEP) dan sebuah lompatan (JUMP) terjadi urut seperti ini, 2) jangkit dilakukan dengan si pelompat mendarat dengan kaki yang sama sesudah bertolak atau kaki tolak (kaki tumpu dipakai mendarat disusul dengan satu langkah penuh yang mendarat menggunakan kaki yang lain dan diakhiri dengan gerakan lompat) (PASI, 1991: 151)

\section{Strategi pembelajaran lompat jangkit dengan melalui metode bermain}

Bermain dan permainan merupakan bagian hidup dan kehidupan manusia, khususnya bagi anak-anak, bermain tidak bisa dipisahkan dari mereka. Matakupan berpendapat; bahwa bermain adalah pekerjaan yang dilakukan dengan senang hati, akan tepat sekali bila bermain dan permainan dijadikan modal utama dalam menciptakan situasi belajar (Matakupan, !993: 5).

Lompat jangkit merupakan salah satu nomor atletik yang tercantum dalam GBPP, dan merupakan mata pelajaran 
inti yang wajib diikuti oleh semua permainan; dan 3) ritmik dan permainan peserta didik. Agar pembelajaran atletik adalah suatu daya kehidupan yang vital menyenangkan, maka pembelajaran dan dapat menimbulkan kegembiraan, perlu dimodifikasi dan disesuaikan kegairahan, kelincahan, relaksasi, dan dengan tingkat pertumbuhan dan yang bermanfaat untuk memudahkan perkem-bangan anak. Menurut ahli timbulnya inspirasi. Manfaat permainan atletik Lange Gunter berpendapat dalam pembelajaran atletik, meliputi: 1) bahwa: Atletik dapat dilakukan secara mengembangkan gerak berirama; 2) bermain ditunjukan pada aaspek ak- memberikan nuansa kompetisi/

tivitas bermain dalam atletik. Fokusnya pada saran-saran dan kemungkinankemungkinan pendidikan atletik yang diantara peserta didik; 3) penggunaan dapat dipandang dari berbagi segi, alat bantu yang variatif dapat digunakan menarik dan penuh event (Lange Gunter, dalam permainan dapat memberikan 1995: 1).

kegembiraan dan kepuasan kepada peserta didik; 4) penggunaan alat bantu

Untuk itu, permainan atletik yang yang menarik dan mudah, menempatkan digunakan dalam proses pembelajaran peserta didik pada penguasaan penuh, keterampilan dasar lompat jangkit perlu sehingga mereka tidak segan-segan mengutamakan unsure kegembiraan dan mengambil resiko untuk memperoleh kesenangan. Permainan atletik meru- kemenangan; dan 5) menguji ketangpakan modifikasi mater pembelajaran kasan yang tersembunyi (menggali keterampilan dasar lompat jangkit kompetisi peserta didik).

sebagai pelatihan awal/pendahuluan untuk memudahkan peserta didik Pelaksanaan pembelajaran teknik melakukan teknik dasar sebelum teknik lompat jangkit melalui metode dasar yang sebenarnya. Meodifikasi bermain merupakan penyederhanaan dari peraturan sarana dan prasaran telah diubah dan disesuaikan dengan kebutuhan dan kemampuan peserta didik. Ini berarti dengan modifikasi diharapkan suasana pembelajaran keterampilan dasar lompat jangkit lebih menarik dapat dilakukan dan diikuti peserta didik tanpa merasa takut dan gagal dalam tugas gerak.

Implementasi pendekatan pola gerak dominan dalam pembelajaran atletik di sekolah dasar meliputi: 1) proses pembelajaran yang hanya berorientasi kepada hasil tanpa memperhatikan variasi dan proses pengembangannya sering menjebak peserta didik dalam kebosanan; 2) pendekatan yang dapat membantu menyegarkan kembali nuansa atletik yang sementara ini dianggap sebagai pembelajaran yang monoto, membosankan dan tanpa variasi adalah melalui dimensi ritmik dan

Hasil belajar, menyeleksi dan menkombinasikan ketrampilan-ketrampilan tekinik-teknik dan ide-ide yang sesuai dengan olahraga perorangan (atletik). Beberapa indikator: 1) mendemonstrasikan teknik yang baik dalam semua tahap lari atau nomornomor lari; 2) mengaplikasikan berbagai teknik lompat jauh, lompat jangkit dan lompat tinggi; 3) memilih pendekatan dengan event yang dihadapi; 4) melakukan berbagai usaha dalam kompetisi; dan 5) menekankan kapan penggunakan power dan kapan menggunakan control yang baik.

\section{Metodologi}

Sampel dalam penelitian ini yaitu siswa kelas lima sekolah dasar yang memperoleh mata pelajaran pendidikan jasamani. Waktu yang digunakan dalam pengambilan data adalah tiga jam 
pelajaran (3x45 menit), dengan rincian Hasil Penelitian dan pembahasan dua jam untuk pelaksaan pembelajaran dan satu jam untuk evaluasi (tes). Dalam pelaksaan pembelajaran guru menggu- meminta peserta didik melakukan nakan alat peraga lompat jangkit yaitu pemanasan di lapangan dengan berlarikertas warna merah berbentuk persegi kecil berkeliling lapangan sebanyak tiga panjang dan kertas warna biru berbentuk kali. Semua mata peserta didik tertuju lingkaran. Kertas warna merah harus pada kertas berwarna-warni dengan diinjak oleh kaki kanan dan kertas warna bentuk yang berbeda. Kertas warna biru berbentuk lingkaran diinjak oleh tersebut dibentuk lingkaran, persegi kaki kiri dengan metode bermain. panjang di tengah lapangan. Guru mulai Kemudian kertas-kertas warna tersebut melakukan pembelajarannya. Dengan diatur sesuai kebutuhan. Pada awalnya meminta siswa mengacak kertas-kertas kertas warna-warni disusun dengan berwarna tadi dengan menjelaskan berurutan sehingga peserta didik mudah kertas-kertas tadi sebagai alat bantu melakukannya kemudian, susunan kertas lompat jangkit.

diatur secara tidak berurutan sehingga peserta didik memerlukan pemikiran dan pemahaman untuk melakukan injakan kaki pada kertas-kertas tersebut dan agar tidak salah.

Untuk setiap kertas warna merah berbentuk persegi panjang sebagai tanda bahwa boleh diinjak dengan kaki kanan, sedangkan kertas warna biru berbentuk lingkaran sebagai tanda untuk boleh

Untuk melakukan pengamatan diinjak dengan kaki kiri. Guru menyusun pembelajaran digunakan pedoman obser- kertas wana-warni tadi dengan urutan vasi dan untuk meminta pendapat peserta yang tidak sama yaitu merah-birudidik tentang rasa senang dan rasa puas merah-biru sebanyak enam warna merah pada strategi pembelajaran teknik lompat dan enam warna biru. Guru meminta jangkit dengan melalui metode bermain. siswa melakukan kegiatan berjalan Teknik pengambilan data menggunakan diatas kertas warna merah dan biru angket/ kuesioner. dengan kaki kanan harus menginjak warna merah dan kaki kiri menginjak

Hasil pengamatan langsung dan warna biru. Semua siswa melakukannya kuesioner dilakukan analisis untuk sebanyak tiga kali, sebagai pemanasan melihat hubungan antara pengamatan dan menghafal kakii mana yang langsung dengan hasil kuesioner. Di digunakan untuk menginjak kertas samping itu, dilakukan studi doku- warna-warni. Bagi siswa yang melamentasi dengan mebandingkan antara kukan kesalahan diberi hukuman push up prestasi siswa sebelum penerapan sebanyak tiga kali. Selanjutnya, siswa strategi pemebelajaran teknik lompat diminta lari-lari kecil di kertas warnajangkit dengan metode bermain dan warni tadi, sesuai kesepakatan jika setelah penerapan strategi pembelajaran peserta didik melakukan kesalahan tersebut dilaksanakan, maka dianalisis, menginjak kertas warna akan mendapat apakah ada penigkatan prestasi siswa hukuman. Kemudian kertas warna-warni sebelum dilakukan strategi pembelajaran diatur dengan jaraknya satu dengan yang teknik lompat jangkit dan setelah lainnya agak berjauhan, dan peserta dilakukan eksperimen tersebut?

didik melakukan lari yang agak lebih cepat dari yang terdahulu. Sambil member istirahat dan siswa berpikir, guru mengatur karpet lebih agak sulit 
dengan cara tidak beraturan. Kemudian, siswa untuk beristirahat dan berganti guru meminta siswa melakukan kegiatan pakaian untuk selanjutnya mengikuti lari-lari kecil atau melangkah cepat di pelajaran berikutnya. Sambil beristirahat atas kertas warna warni tadi. Sesuai tampak jelas setiap wajah siswa terlihat dengan kesepakatan bersama antara guru senang dan gembira meskipun badan dan siswa, bagi siswa yang melakukan terasa sangat letih.

kesalahan dengan menginjak kertas

warna-warni tadi tetap diberi hukuman yang berupa wujud untuk memotivasi

Kreativitas guru menciptakan siswa agar tidak melakukan kesalahan.

media pembelajaran berupa kertas warna yang dibentuk persegi panjang maupun lingkaran yang digunakan untuk perma-

Permainan dilakukan dua atau tiga inan dalam teknik lompat jangkit sangat kali sampai siswa tidak lagi melakukan baik sekali dan membuahkan hasil yang kesalahan yang sama. Selanjutnya siswa positif. Prestasi belajar siswa akan diminta beristirahat sejenak dan meningkat. Sebelum dilakukan kegiatan sementara guru mengatur kembali su- pada pembelajaran yang dilakukan guru sunan kertas warna-warni secara tidak nilai rata-rata siswa adalah 6,38 dan teratur dan cukup sulit dan dengan jarak setelah dilakukan kegiatan pembelajaran antara kertas warna merah dan warna dengan kreativitas guru mengunakan biru tertentu dengan tujuan adanya media pembelajaran, maka nilai rata-rata keseimbangan. Setelah istirahat guru siswa meningkat menjadi 7,28. Hal meminta kembali siswa untuk berlari tersebut mengindikasikan bahwa adanya satu persatu berdasarkan urutan absensi peningkatan prestasi belajar yang dengan untuk dinilai. Dalam melakukan peni- demikian bahwa kreativitas yang laian guru bersikap luwes dan fleksibel dilakukan guru tersebu tidak sia-sia atau dan tidak kaku, sehingga siswa tidak menarik minat siswa. Tampaknya merasa sedang dinilai oleh guru karena memang sederhana, hanya berupa kertas situasi siswa dalam kondisi bermain yang dibentuk bangun datar, namun bagi sehingga tidak ada perasaan tertekan, siswa kreativitas guru tersebut sangat takut atau cemas akan melakukan memotivasi siswa untuk melakukan kesalahan dalam lompat jangkit. Siswa suatu hal yang terbaiknya. Baik dalam merasa senang melakukan permainan melakukan lompatan maupun saat tersebut walaupun sedang dinilai oleh menjalani hukuman dimana apabila guru, tapi siswa tetap bergembira dan siswa melakukan kesalahan dalam bersenda gurau dengan teman-temannya. menginjak kertas warna warni sesuai Gurupun tidak mengalami kesulitan dengan kesepakatan. Dalam hal ini dalam melakukan penilaian karena dibuktikan bahwa dalam diri siswa telah semuanya berjalan dengan wajar dalam tertanam rasa tanggung jawab dan situasi bermain. sportivitas yang tinggi. Selain itu telah

Meskipun siswa dihadapkan pada dapat memotivasi siswa untuk bersikap dan berbuat jujur.

permainan yang agak menantang lagi karena harus melakukan gerak kaki dan

Apabila siswa melakukan kesaberpikir untuk tidak melakukan kesa- lahan dengan menginjak kertas warna lahan. Namun semua itu dilakukan oleh dengan kaki yang salah maka dengan siswa dengan hati gembira dan dalam suka rela dan penuh tanggung jawab situasi bermain sehingga semuanya siswa tersebut akan menjalani huberjalan lancar. Setelah semua siswa kumannya tanpa diminta oleh guru atau melakukan tugas dan tanggung jawabnya teman-temannya. Dengan penuh kesadan dinilai, kemudian guru meminta daran atau rasa tanggung jawab yang 
tinggi itulah siswa akan menjalani SIMPULAN DAN SARAN hukuman dengan melakukan push up sebanyak tiga kali. Apabila kebiasaan Simpulan

berbuat jujur terus dikembangkan dan dipelihara, maka pada akhirnya tercipta manusia-manusia unggulan, berkarakter yang baik sebagai sumber daya yang berkualitas, jujur sehingga mampu bersaing di era global.

Dalam melaksanakan pembelajaran, guru telah dapat membuat siswa tig merasa senang dan tidak tertekan san takut. Apabila peserta didik takut mendapat hukuman selalu merasa senang pada setiap melakukan kesalahan. Kertas disusun mengikuti pembelajaran, maka siswa kembali dengan susunan agak sulit juga akan menyenangi materi yang dengan maksud agar siswa dapat berpikir diajarkan guru maupun mata pelajaran terlebih dahulu sebelum melakukan tersebut secara utuh. Apabila dalam lompatan. Tanpa disadari siswa telah setiap pembelajaran guru selalu merujuk mampu menghadapi tantangan yang pada setiap prinsip dalam pembelajaran cukup sulit yang diberikan oleh guru dan adalah pembelajaran yang dimana siswa mampu melakukan lompatan melibatkan si belajar ( siswa ) secara ak- jangkit dengan baik tanpa melakukan tif, serta membuat si belajar (siswa) kesalahan. Terjadi peningkatan prestasi, kreatif sehingga pembelajaran tersebut yang sebelumnya nilai rata-rata siswa dapat berlangsung secara efektif, efisien 6,38 dan setelah menerapkan strategi dan juga menyenangkan bagi si belajar pembelajaran teknik lompat jangkit ini (PAKEM). Siswa merasa senang dalam prestasi belajar siswa meningkat menjadi melakukan kegiatan belajar, semua yang 7,28.

diberikan guru juga pada akhirnya dapat dipahami dengan baik dan membuat siswa mampu menerapkannya dengan baik pula. Dengan demikian setiap pembelajaran yang dilaksanakan oleh guru dapat menampilkam kreativitaskreativitasnya yang menyenangkan. Diharapka ,siswa jangan terpacu untuk melakukan kreativitas. Siswa dapat memilih media pembelajaran sesuai materi yang diajarkan dan dicontohkan guru maupun alat-alat atau media lainnya yang baru sebagai hasil kretivitasnya. Sehingga pada akhirnya akan tercipta manusia-manusia kreatif yang dapat menciptakan ide atau karya-karya kreasi yang baru berdasarkan contoh yang telah ada, atau menhasilkan sesuatu yang baru sama sekali.

Siswa merasa senang melakukan teknik lompat jangkit dengan melalui bermain, setiap melakukan kegiatan lompat jangkit dilakukannya dengan senang dan gembira begitu juga ketika siswa melakukan kesalahan, maka dengan kesadaran dan tanggung jawab sendiri siswa melakukan push up dengan senang sebagai hukuman tanpa diminta oleh ataupun paksaan dari guru. Saat guru melakukan penilaian terhadap lompatan jangkit tidak ada satupun diantara siswa yang melakukan kesalahan, semua siswa melakukan lompat jangkit dengan baik dan sempurna. Ketika selesai melakukan lompat jangkit dengan penuh canda peserta didik beristirahat dan berganti pakaian olahraga dengan seragam sekolah putih- 
merah kembali mengikuti pelajaran berikutnya.

Saran

Diharapkan agar guru selalu Jasmani di Sekolah Dasar, Lembaga berusaha membuat persiapan pembe- Penelitian IKIP Surabaya. lajaran dengan sebaik-baiknya, mengacu pada pembelajaran yang berpusat pada siswa sebagai si belajar. Siswa sebagai subjek menjadi tolak ukur pembelajaran
yang dilaksanakan guru sehingga akan selalu berusaha membuat siswa merasa senang dalam setiap kegiatan pembelajaran.

Diharapkan agar setiap Guru pendidikan jasmani sebaiknya terlibat langsung dalam seluruh aktivitas kegiatan pembelajaran yang dilaksanakan dan terus memperhatikan kegiatan siswa tersebut dengan seksama serta jangan membiarkan siswa melakukan gerakan atau permainan sesuai kemauan siswa dan guru hanya duduk-duduk saja di pinggir lapangan sementara siswa berada di tengah lapangan. Apabila setiap pembelajaran yang dilaksanakan guru dapat melibatkan siswa secara aktif dan kreatif, dan membuat siswa merasa senang maka sangat dimungkinkan akan tercipta manusia-manusia unggul sebagai sumber daya yang berkualitas yang mampu bersaing di era global sekarang ini.

\section{DAFTAR PUSTAKA}

Bucher, C.A. 1983. Foundation of Physical Education and sport, st. House CV. Mosby.

Department Pendidikan Nasional, 2002, Kurikulum Berbasis Kompetisi. Jakarta.

Lange Gunter. 1995. Manual Actual Knowledge for Indonesia Level I Coacher, Jakarta.
Matakupan. 1993. Materi Pokok

Mutohir. 1996. Pengembangan Model Pembelajaran Pendidikan

Persatuan Atlet Seluruh Indonesia. 1991. Anggaran Dasar dan Rumah Tangga. PASI 1990-1991 Jakarta.

Slavi, R.E. 1994. Education Psychology: Theory Research and Practice. Second Edition. Boston: Allyn and Bacon. Teori Bermain, Jakarta. 